\title{
A CELEBRIZAÇÃO DO JOGADOR DE FUTEBOL NEYMAR: O DISCURSO DO PROGRAMA ESPORTE ESPETACULAR VERSUS DISCURSO DE JOVENS UNIVERSITÁRIOS
}

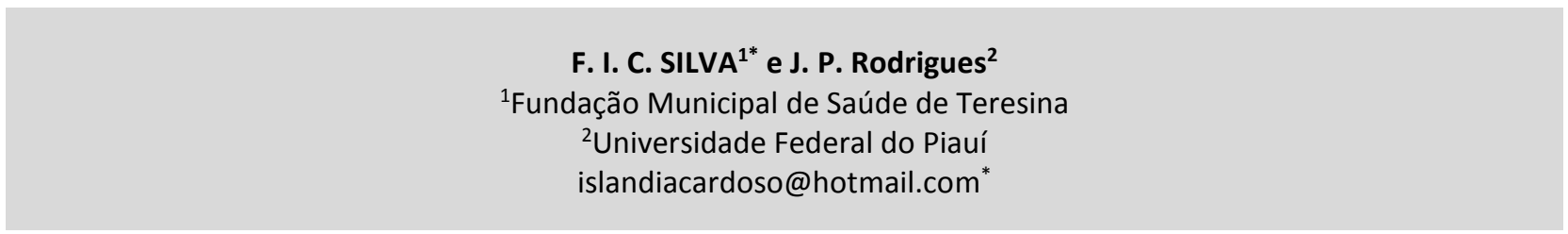 \\ Artigo submetido em outubro/2015 e aceito em novembro/2015 \\ DOI: $10.15628 /$ holos.2015.3588
}

\section{RESUMO}

O objetivo desta pesquisa é investigar os sentidos de celebrização de Neymar presentes em uma matéria do programa Esporte Espetacular (EE) e no discurso de jovens universitários. Fez-se uso da técnica de grupos focais e do método analítico-descritivo para coleta e análise dos dados, respectivamente. A amostra foi constituída por 24 jovens universitários, na faixa etária entre 18 e 24 anos. A reportagem se centrou na exaltação e valoração da imagem de Neymar e na criação do mesmo como ídolo. Os sentidos propostos pelo EE não foram adotados pelos jovens, comprovando, assim, que o receptor processa as mensagens à sua maneira.

PALAVRAS-CHAVE: Celebridade, recepção midiática, televisão, Neymar.

\section{THE CELEBRITIZATION OF SOCCER PLAYER NEYMAR: SPEECH OF PROGRAM SPECTACULAR SPORT VERSUS SPEECH OF YOUNG COLLEGE}

\section{ABSTRACT}

The objective of this research is to investigate the senses of celebritization of Neymar present in a report of Sports Spectacular program and discourse of the college young. Was used the technique of focus groups and analyticaldescriptive method for collecting and analyzing data, respectively. The study sample consisted of 24 college
\end{abstract}

students aged between 18 and 24 years. The report focused on the exaltation and valuation of Neymar image and in his creation as an idol. Young, proving that the receiver processes the messages your way, did not adopt the senses proposed by EE.

KEYWORDS: Celebrity, media reception, television, Neymar. 


\section{INTRODUÇÃO}

Segundo Douglas Kellner (2004, p. 6), a celebridade se sustenta pela sua representatividade no campo cotidiano, ou seja, "para alguém se tornar uma celebridade é preciso ser reconhecida como uma estrela no campo do espetáculo, seja no esporte, no entretenimento, ou na política".

Através do conceito de retórica visual dos personagens, Verón (2004, p. 175) ressalta que para cada personalidade, a mídia constrói uma imagem, "um conjunto de traços que, em virtude dessa construção, se convertem em índices de reconhecimento do personagem, de sua imagem". Por meio de uma coletânea de ocorrências, os personagens atuarão segundo a interpretação que se pretende passar em determinado instante.

Em meio aos critérios para a consagração de uma celebridade, que alie os elevados índices de audiência e uma identificação com os espectadores/consumidores, surge Neymar como uma nova personalidade do universo imaginário dos consumidores da crescente indústria do entretenimento. O protagonismo de Neymar é notório pelo uso de sua imagem em todos meios de comunicação - desde televisão, revistas e internet - e também pelo grande interesse de patrocinadores locais e globais. A imagem do jogador ultrapassou o segmento esportivo e hoje ele é constantemente apresentado na narrativa midiática como uma personagem capaz de ofertar elementos e sentidos desencadeadores de constructos comportamentais, ideológicos e imagéticos na audiência de jovens brasileiros.

No entanto, segundo Wolf (1995), apesar dos meios de comunicação montarem estratégias a fim de atrair o receptor a consumir seus produtos, o último não é passivo - como assim defendia o paradigma comunicacional funcionalista -, mas está sujeito a diversos fatores internos e externos que o orientam em suas escolhas. Na visão do autor,

É neste quadro que toda a hipótese do efeito linear do conteúdo dos mass media sobre as atitudes, valores ou comportamentos do público, é invertida, na medida em que é o receptor que estabelece se existirá, pelo menos, um processo comunicativo real (WOLF, 1995, p. 69).

Sabendo-se que a juventude é constituída socialmente sob as mais diversas influências, em que ideias e valores são constantemente confrontados, pressupõe-se que a mídia seja um equipamento social no sentido de produzir esquemas dominantes de significação e interpretação do mundo ao direcionar sobre o que pensar.

\section{PROCEDIMENTOS METODOLÓGICOS}

A opção por trabalhar com o programa Esporte Espetacular deu-se em razão deste ser um dos principais telejornais esportivos de transmissão nacional do Brasil e, também, da maior facilidade de acompanhamento das matérias e coleta e registro das informações. A reportagem selecionada, intitulada pelo EE como "Muricy Ramalho afirma que é natural Pelé dar conselhos para Neymar", foi exibida em 24 de fevereiro de 2013.

Para análise do conteúdo da matéria do EE e das respostas obtidas por meio dos grupos focais utilizou-se o método analítico-descritivo, que, segundo Minayo (2008), é aplicável a estudos que objetivem compreender a dinâmica de um determinado fenômeno através do estudo e 
avaliação aprofundados de informações disponíveis sobre este e, assim, interpretá-lo e explicar seu contexto e as variáveis envolvidas.

A amostra do estudo foi constituída por 24 jovens universitários na faixa etária entre 18 e 24 anos, de ambos os sexos. A escolha por universitários se deu em decorrência de considerar que a educação pode ampliar a capacidade de pensar e contribuir para a formação de um homem preocupado com a coletividade, apto a levar a efeito ações que possam mudar a sociedade (VYGOTSKY, 2004).

A amostra foi constituída conforme o método de conveniência, um dos mais flexíveis métodos de amostragem e, por isso, privado de rigidez estatístico (MARCONI; LAKATOS, 2009). Os participantes foram selecionados admitindo-se que pudessem de alguma forma representar a população de jovens universitários do curso de Educação Física da Universidade Federal do Piauí.

Considerando as vantagens financeiras e práticas, a pesquisa utilizou como estratégia inicial de recrutamento de participantes convites divulgados em redes sociais. Nos convites foram apresentados os objetivos da pesquisa, metodologia e custos e benefícios relacionados à possível participação. Para tornar maiores as taxas de resposta foram enviados lembretes periódicos, ao longo de um mês, para a participação ou disposição com outros dispositivos, como o Whatsaap. Após o contato virtual e caso o participante aceitasse, agendou-se um contato presencial entre a autora do estudo e os jovens universitários para esclarecimentos sobre a pesquisa e cadastro dos interessados em participar. Logo depois, foram organizados os grupos focais e marcadas as sessões. Para montagem dos grupos focais, além de abarcar os critérios de participação anteriormente expostos, seguiu-se dois critérios: (i) evitou-se alocar em um mesmo grupo pessoas do mesmo círculo imediato de convivência; (ii) apenas estudantes do curso de Educação Física poderiam participar. A exigência do último critério dá-se em decorrência da reponsabilidade do professor de educação física em estar atento às mais variadas informações esportivas transmitidas pelos meios de comunicação de massa e usá-las a seu favor para que possa elucidar a seus alunos ideologias presentes no discurso midiático e mediar a produção de sentidos acerca do esporte moderno.

Os dados foram colhidos por intermédio de grupos focais, e as entrevistas gravadas e transcritas. Conceitualmente, o grupo focal é uma técnica de entrevista utilizada em pesquisas qualitativas, que tem o propósito de coletar dados através da interação grupal e consiste em uma exposição oral específica dos envolvidos para que o pesquisador possa obter mais respostas através de sondagens sobre as razões ocultas em relação a um determinado comportamento dos participantes (MUNARETTO; CORRÊA; CUNHA, 2013).

O grupo focal girou em torno da temática da peça jornalística, sem, no entanto, desprezar as informações diversas que por ventura surgissem durante o grupo focal desde que pertinentes ao tema da pesquisa. Na sessão, os participantes assistiram à peça jornalística e a seguir foram solicitados pela mediadora - papel exercido pela autora do presente estudo - a verbalizar suas impressões sobre o que tinham assistido.

Foram realizados três grupos focais com oito jovens em cada grupo em função da complexidade do tema. Os grupos focais foram compreendidos como contextos únicos por serem constituídos por pessoas diferentes. 
Conforme as condições apresentadas no Termo de Consentimento Livre e Esclarecido (TCLE) entregue a cada um dos participantes, os mesmos estavam cientes de que as informações por eles concedidas seriam usadas exclusivamente para a pesquisa em questão e que os seus nomes seriam mantidos em sigilo.

O presente estudo foi aprovado pelo Comitê de Ética em Pesquisa da Universidade Federal do Piauí - UFPI sob parecer no 874.966.

\section{RESULTADOS E DISCUSSÃO}

\subsection{O discurso do Esporte Espetacular acerca de Neymar}

Ao ser eleito pelo público e pela mídia como o melhor jogador brasileiro de futebol em atividade, a representação midiática de Neymar alcança outros pináculos salvo o estatuto de craque futebolístico. Destarte, os meios de comunicação brasileiros passam a incorporar/enaltecer o personagem nos seus mais diferentes conteúdos e produtos. Assim, por meio do desempenho como ídolo, não tardou para que a mídia produzisse e/ou causasse o reconhecimento de mais uma estrela para o entretenimento.

Exibida em 24 de fevereiro de 2013, a reportagem tem como pauta principal a forma como Neymar estava se apresentando (ou sendo apresentado) ao público, como uma celebridade. A reportagem é iniciada com a caracterização de Neymar como rico, famoso, bom de bola e de vendas. Wagner Ribeiro, empresário de Neymar, afirma que quem quer que sua marca seja vista por milhões de pessoas contrata o Neymar. Fãs afirmam que Neymar é lindo, maravilhoso. 0 narrador da matéria relata a rotina diária de Neymar: eventos, festas, gravações de comerciais, sessões de fotos, passeios em seu carro de luxo. Em seguida, revela-se que que essa "badalação" incomodou o ex-jogador de futebol Pelé, o qual teceu duras críticas ao comportamento de Neymar fora dos campos e referiu que ele se preocupava mais com a aparência e visibilidade na mídia do que com a boa execução de sua profissão, jogador de futebol. As críticas surgiram na mesma semana em que Neymar foi expulso numa partida do campeonato paulista. A reportagem mostra o momento da expulsão de Neymar da partida e sua explicação para o ocorrido. "Foi uma jogada normal dentro de área. Todo mundo se chuta, se bate ali, mas pra expulsão ele (árbitro) apelou", explicou o jogador.

Com o objetivo de esclarecer se a vida de celebridade atrapalha o desempenho profissional de Neymar, o programa decidiu entrevistar quatro pessoas ligadas ao jogador: Paulo Henrique Ganso, Dorival Júnior, Wagner Ribeiro e Muricy Ramalho. Segundo os entrevistados, o furor sobre Neymar é consequência de sua habilidade e talento como jogador de futebol.

Ao fim da matéria, exibe-se uma mensagem publicada por Neymar em uma rede social: "muito orgulhoso por ser o oitavo brasileiro a ser capa da Time. Orgulho maior ainda ao ser comparado ao incomparável Pelé". Segundo a matéria essa declaração de Neymar foi uma ótima forma de se esquivar de qualquer polêmica relacionada a Pelé.

Deve-se salientar a representatividade de Pelé, uma vez que é estimado como o melhor jogador de futebol de todos os tempos. Ao optar por Neymar como pauta de matéria e pô-lo ao lado de Pelé, O EE deseja gerar um vínculo entre o craque do passado e o craque do presente/futuro, demonstrando assim que aposta em Neymar como sucessor no posto de ídolo esportivo nacional antes ocupado por Pelé. 
O esporte vem se traduzindo em conteúdo cada vez mais influente no jornalismo, graças, principalmente, à visibilidade proporcionada pela sociedade do espetáculo (DEBORD, 1997) a este espaço e os exorbitantes valores financeiros que o perpassam. O discurso do EE é envolvido pelo discurso do esporte-espetáculo, o qual se mantém através da criação estratégica de ídolos. A carência de um ídolo nacional é o pilar argumentativo para a decisão do EE em apoiar a candidatura de Neymar a tal posto. Aliar a imagem de Pelé a Neymar - mesmo que em um contexto de aparente desavença entre os jogadores - propõe uma situação em que a promessa do futebol brasileiro, ou melhor, dos novos tempos do futebol brasileiro, estaria sob a orientação do ídolo do passado, indicando a magnitude que o percurso profissional de Neymar poderia trilhar.

Para apresentar Neymar, o EE faz uso de algumas expressões linguísticas. "Bom de bola" refere-se ao status de expoente do futebol, jogador habilidoso. Os termos "rico", "famoso" e "bom de vendas" referem-se à riqueza do jogador e de sua condição de celebridade.

Detentor de 11 patrocinadores pessoais, Neymar é apontado pelo EE como marca, fortalecendo a intertextualidade entre o discurso das/sobre celebridades e o discurso mercadológico, pois ao agir sobre o desejo, Neymar converte-se em mercadoria. Nessa perspectiva, o desempenho profissional e o sucesso dos ídolos se transformam em bens de consumo.

O EE deixa patente que Neymar é um símbolo potencial dentro do futebol e aclamado fora dos campos. Consoante Helal (2003), transformados em celebridades, os ídolos do cenário esportivo são considerados heróis, construídos a partir de narrativas que justificam tal mitificação. Para o autor, "a explicação para este fato reside no aspecto agonístico, de luta, que permeia o universo do esporte" (p. 19), que tem a vitória e a derrota como inerentes ao próprio espetáculo.

Se Neymar é uma marca, quais os produtos ofertados? Desde o corte de cabelo até o vestuário do jogador. Tudo isso é consumido por sujeitos atraídos pela notoriedade a que tal comportamento pode conduzir. Na sociedade atual os sujeitos não necessariamente devem obter produtos, mas fundamentalmente aparentar tê-los, o que termina por facilitar o consumo. Os consumidores da marca Neymar põem em seus produtos a expectativa de que estes podem darIhes relevância frente à sociedade. O importante, portanto, acaba por não ser Neymar, mas sim as consequências a que este pode levar: a riqueza e a fama citadas na reportagem.

O EE diz que Neymar é uma marca, porém faz parecer que isso é mérito exclusivo do jogador quando, na verdade, a mídia desempenha importante papel na construção dessa marca. Barthes (2001) compreende que o mito por ser fala é signo, logo, pode ir se formando no imaginário social através de representações, vocábulos, expressões, espetáculos, entre outras maneiras de sociabilidade. Se o mito é uma fala, os meios de comunicação podem servir de apoio para sua construção, pois a superexposição causada pela mídia reforça as estratégias discursivas e imagéticas.

Sabe-se que a sociedade se apresenta escorada no sensacionalismo e no espetáculo. Só há valor em determinado produto quando este é apresentado pelos meios de comunicação de massa. Assim, a mídia influencia a cultura e o sujeito ao oferecer possibilidades de identidades a serem consumidas. A expressão de Hall "supermercado cultural" (2005, p. 75) parece a mais pertinente para este contexto da identidade, um território onde é possível escolhê-la através do que é consumido. Por isso, quando questionado sobre "quem é", a resposta tende a ser gostos em música, arte, gastronomia e hobbies (CAMPBELL, 2006). Construir a identidade também significa 
escolher as marcas que melhor representam o indivíduo. Com o interesse de conquistar o consumidor, a mídia - inclusive o Esporte Espetacular - consegue administrar a transformação de fatores emocionais na commodity de Neymar. O processo de racionalização do afeto ocorre ao converter a individualidade em um sistema de troca, e ao forjar o reconhecimento pelo público de valores culturais e formas de identificação em Neymar. As características enaltecidas durante a matéria do EE e ofertadas ao público foram: fama, juventude e riqueza.

O jovem anseia pelo reconhecimento e para isso adota marcas de identidade que aumentem a possibilidade de exibir-se e ser reconhecido a partir disso. Não mais basta "ser" ou "ter", é preciso agora, principalmente, "parecer". Entretanto, esse "parecer" não pode se afastar do elemento real, pois além de levar em consideração o que o público deseja, deve-se tomar o devido cuidado para não soar falso. Isso leva a crer que os sujeitos desejam mostrar-se ao Outro de forma espetacularizada e, para tanto, trocam uma identidade considerada ultrapassada por outra que o legitime na medida em que consomem determinados itens vendáveis/atrativos para o Outro como, por exemplo, a marca Neymar. Indo de encontro a Guy Debord (1997), o público jovem deseja não apenas um conjunto de imagens, mas recursos de visibilidade e reconhecimento.

Para consolidar-se na indústria do entretenimento, um ídolo deve possuir um poderoso recurso para progredir no cenário midiático: fãs. Segundo o EE tudo o que Neymar "faz tem repercussão imediata". A reportagem retrata o frenesi de fãs do jogador ao mostrá-los usando máscaras de Neymar, tirando fotos, copiando os trejeitos e penteados, pedindo autógrafos ou gritando para chamar a atenção do jogador celebridade. Mudou o cabelo, virou assunto. Essa demonstração de admissão de Neymar pelo público o reitera como ídolo. A mensagem "não é que o modelo oxigenado agradou" notabiliza a firmeza da carreira de Neymar e a empatia com o público, já que a cor do cabelo é em si um fato banal, mas é tratada pelo público - segundo o EE como uma informação de suma importância sobre o jogador. Uma fã chega a dizer que Neymar "fica lindo de qualquer jeito", mostrando que o jogador dimensionou sua fama para além dos campos e faz também papel de símbolo sexual. Esse fato mostra o interesse pela vida particular do ídolo, que oculta a vontade de atingir a fama. Atualmente não é necessário nenhum feito extraordinário para que alguém atinja esse nível de reconhecimento. No entanto, a fama instantânea pode ser efêmera, caso os o personagem não tenha mais temas a serem midiatizados. A reportagem apresenta um Neymar que sempre tem algo diferente para o público nos jogos de futebol, em eventos, redes sociais ou comerciais.

Na perspectiva adotada por este estudo, o poder da mídia reside no poder de conceder visibilidade ao social e criar e legitimar sentidos, propagando as vozes constituintes de um tempo histórico específico (TRAQUINA, 1999).

A respeito da crítica tecida por Pelé, o EE exibiu depoimentos de pessoas diretamente ligadas ao jogador: Paulo Henrique Ganso (jogador e amigo de Neymar), Dorival Júnior (ex-técnico do Santos), Wagner Ribeiro (agente de Neymar), Muricy Ramalho (técnico do Santos na época). Dentro de um processo que Charaudeau (2010) concebe como um modo de incitar o debate social sobre determinado tema, a matéria possibilitaria o confronto de ideias. Porém, esse embate não aconteceu, e a escolha dos depoentes faz com que se questione a imparcialidade do EE.

Ciente de sua influência nos pressupostos e crenças compartilhados na sociedade, o EE adaptou sua mensagem (carregada de valorações ao que consomem e decodificam os telespectadores) e utilizou os depoimentos com objetivo de auxiliar na legitimação de seu juízo 
quanto à crítica feita a Neymar. Os citados depoentes foram ouvidos como autoridades com total legitimidade para falar sobre a atuação do jogador; atribuiu-se a eles o papel de porta-vozes da opinião pública e não da individual.

Bourdieu (2007) propõe que as ações e o pensamento de um enunciador estão sujeitos às circunstâncias em que esses arranjos são gerados, ou seja, de sua posição social em um espaço formado por diferentes campos, com lógicas e relações específicas. Logo, os discursos são consequência de um extenso processo de socialização. Assim, os atores disputam por posições de legitimidade em cada campo na tentativa de poderem proferir determinados tipos de discursos e fazerem valer seus critérios para o restante da sociedade.

O prestígio e o reconhecimento profissional de um programa jornalístico resultam de suas fontes e de sua familiaridade com o poder. Isso significa que atletas e técnicos - além da alta cúpula de um clube ou federação - conferem autoridade e legitimidade para os veículos de comunicação, e vice-versa. Além de Wagner Ribeiro, empresário de Neymar, o EE convocou técnicos e jogador de futebol - tidos como autoridades no campo futebolístico por sua boa reputação e popularidade - para discursar acerca da crítica de Pelé.

O tratamento dado pela peça se apresenta revestido de uma voz de legitimação de poder, como defende Maingueneau (1997), por ser divulgada por um veículo de circulação e importância nacional e passível de formação de opiniões. O aval positivo do EE para as ações de Neymar e negativo para a crítica de Pelé ratifica a hipótese de Bourdieu (1989) de que a mídia cria um "capital transferido" para dar um caráter legítimo aos atores. As características, qualidades e o reconhecimento obtido por Neymar no campo profissional valem na competição pelo poder também no espaço pessoal. Logo, quando o empresário Wagner Ribeiro diz que "a agenda dele [Neymar] é muito cheia, mas ele nunca faltou um treinamento", a característica "responsável" é tida como intrínseca ao jogador em qualquer âmbito de sua vida.

Para o EE, Neymar não cometeu nenhum erro, pelo contrário, o jogador seria uma vítima do próprio sucesso profissional. Para o programa, não é Neymar quem busca a mídia e os fãs, mas o contrário, ele é procurado incessantemente por esses grupos. Acontece que apesar do "ídolo Neymar" ter nascido no seio da mídia de massa e permanecer vinculado a ela, isso não significa que ele seja totalmente controlado pelas mãos desta. Há uma negociação entre o público, a mídia e o ídolo. Enquanto representação, Neymar assume a forma de personalidade, pela qual passa a ser reconhecido. Essa representação torna-se objeto de forte apelo comercial e, como tal, precisa ser bem gerenciada. Sabedor da curta vida como celebridade, é habitual que os sujeitos busquem assessoria especializada para vender-se melhor, modelar e administrar suas imagens. Esse também é o caso de Neymar, que conta com a assessoria da 9ine Sports \& Entertainment, agência de comunicação com olhar estratégico para o esporte e o entretenimento. Neymar, então, consente mostrar-se como mercadoria a ser explorada pela mídia.

Não bastassem os depoimentos, o EE destacou que na mesma semana do "puxão de orelha" de Pelé, Neymar foi capa da revista Time, algo que segundo o programa é uma façanha, pois foi a primeira vez que um esportista brasileiro conseguiu tal feito. Antes de Neymar, outros sete brasileiros estamparam a capa da revista: os ex-presidentes Júlio Prestes, Getúlio Vargas, Café Filho, Juscelino Kubitschek, Jânio Quadros, e, Costa e Silva, além do diplomata Osvaldo Aranha. Segundo o jornalista do EE Renato Peters, a revista chama Neymar de "o novo Pelé". Abaixo capa da citada edição da revista. 
A revista intitula Neymar como "the next Pelé" ("o próximo Pelé", em português). Por que, então, o repórter traduziu como "o novo Pelé"? Já se discutiu aqui que a mudança do caráter e do objetivo essencial da notícia ocorreu com o desenvolvimento da subordinação do meio jornalístico ao setor comercial, o qual determina que conteúdo pode ser produzido e publicado. Com isso o espetáculo ganha força, pois ele maquia, revitaliza ou deturpa a notícia, deixando-a mais atraente e vendável. A pauta, a produção, tudo que faz parte do trabalho de bastidores de uma determinada matéria, por exemplo, é direcionado conforme os acordos e linhas da empresa de comunicação com objetivo de imunizar o sistema e não gerar conflitos com os interesses de seus investidores. É interesse do EE que a imagem de Neymar continue ilibada, pois o atleta é um chamariz de audiência.

Vê-se também que a vinculação de Neymar a Pelé não é gratuita. Muitos jogadores brasileiros chegaram a ser comparados a Pelé ao longo da história, mas, aqui, a filiação é direta "o novo Pelé". É como se Neymar, notabilizado no clube em que Pelé principiou a firmar sua carreira, figurasse como herdeiro do Rei do futebol. Entretanto, salienta-se que nesta filiação (verbal e não verbal - texto e imagem) Neymar não é apresentado como um príncipe, mas como o novo Rei.

À primeira vista o fato da reportagem revelar os questionamentos feitos a Neymar por seus modos de ser e agir pode parecer prejudicial à imagem do jogador, porém ao mostrar a mensagem postada por ele em uma rede social - "muito orgulhoso por ser o oitavo brasileiro a ser capa da Time. Orgulho maior ainda em ser comparado ao incomparável Pelé" -, o EE expõe uma faceta independente (que não se incomoda com o julgamento dos outros), seguro de si e inteligente ("consegue driblar polêmicas") do jogador.

\subsection{Modos de apropriação da reportagem pelos jovens}

Uma notícia pode ser veiculada de várias maneiras por um veículo de comunicação. O G1 considerou que na tentativa de aumentar a audiência o EE utilizou na peça 1, "Muricy Ramalho afirma que é natural Pelé dar conselho para Neymar", um conjunto de elementos que atribuiu ao seu discurso um tom sensacionalista: a edição de imagens, o texto marcante e a dose de teatralização do narrador da reportagem.

Um programa de jornalismo, mesmo o esportivo, deveria ser consciente de seu papel social, correto e idôneo. Mas, o que vi nessa matéria foi um espetáculo de teatro. (Aluno 1, G1)

Conforme Angrimani Sobrinho (1995),

Sensacionalismo é tornar sensacional um fato jornalístico que, em outras circunstâncias editorias, não mereceria esse tratamento. Como adjetivo indica, trata-se de sensacionalizar aquilo que não é necessariamente sensacional, utilizando-se para isso de um tom escandaloso, espalhafatoso. Sensacionalismo é a produção de noticiário que extrapola o real, que superdimensiona o fato (p. 16).

G2 e G3 também consideram que a matéria recorre aos mecanismos do espetáculo e do excesso, mas descartam a possibilidade de sensacionalismo.

Não, sensacionalismo eu não vejo não. O Esporte Espetacular faz as coisas de um 
jeitinho elegante. Programa sensacionalista é todo esculachado, apresentador barulhento. Gente que procura um morto. (Aluna 4, G2)

Como aponta Martín-Barbero (2009, p. 171), o melodrama tende ao esbanjamento, que abrange "desde uma encenação que exagera os contrastes visuais e sonoros até uma estrutura dramática e uma atuação que exibem descarada e efetivamente os sentimentos, exigindo, o tempo todo do público uma resposta em risadas, em lágrimas, suores e tremores". Os discursos de G1, G2 e G3 convergiram ao afirmar que a peça 1 busca despertar a emoção do público e faz isso através do excesso de palavras e adjetivos para caracterizar Neymar, e principalmente pelo tom de voz empregado pelo repórter que expressa suspense, indignação, medo.

Detalhistas, G2 e G3 citaram a predominância da estratégia do close up, utilizada na matéria para exibir os envolvidos (Pelé e Neymar) de modo que o telespectador acompanhe de perto suas expressões faciais, e a trilha sonora de suspense ou tragédia.

Repara aí que eles só mostram o Pelé com o semblante fechado, sisudo. Já o Neymar só aparece sério no momento do jogo, hora em que ele está concentrado trabalhando. Fora isso, é só sorriso. (Aluna 2, G2)

E essa trilha de fim de séries de TV. Se você não se interessar pelo que o repórter fala, mas no mínimo, a trilha te segura no sofá. Me lembrou a trilha do Gladiador. (Aluno 4, G3)

A intenção da narrativa da peça jornalística 1 ao fazer uso de todo esse arcabouço técnico foi pontuada por uma integrante do G3: "o objetivo da matéria é convocar o público, provocar sensações, pra que ele se envolva no discurso do Esporte Espetacular, se identifique com Neymar, suposto injustiçado, e repudie o Pelé, causador do transtorno."

Para Arbex Júnior (2001), uma das consequências de se apresentar o jornalismo em forma de show é o enfraquecimento entre o real e o fictício. Esse procedimento produz uma percepção alterada dos acontecimentos, podendo ser caracterizado, em última instância, como desinformação.

Consoante Foucault (2008, p. 75),

onde há poder, ele se exerce. Ninguém é, propriamente falando, seu titular; e, no entanto, ele sempre se exerce em determinada direção, com uns de um lado e outros do outro; não se sabe ao certo quem o detém; mas se sabe quem não o possui.

Considerando-se que o poder é negociado constantemente conforme o decorrer das situações, os argumentos dos participantes de G1 e G3 trazem um certo ar de dúvida sobre a credibilidade do discurso de Pelé acerca de Neymar e consideram que o primeiro estaria enciumado com a atual posição de ídolo nacional ocupada pelo último. Para os estudantes, Neymar continua a exercer sua profissão de jogador de futebol de maneira excelente e não existem, portanto, razões para cobrança.

É natural essa exaltação de imagens, a superexposição de Neymar em detrimento de outros atletas que ainda não atingiram a consagração como ídolo. Ele é o melhor jogador brasileiro da atualidade. $O$ nível dele não caiu não, pelo contrário. 
(Aluna 3, G1)

Quando passou a figurar como ídolo e a ter maior visibilidade, o passe do Neymar foi valorizado. Ele agora é um bom negócio para os clubes de futebol e, principalmente, para os patrocinadores. Tanto que foi pra Europa já com um grupo de patrocinadores próprios. (Aluno 8, G3)

Da mesma forma que G1 e G3, o G2 ressaltou que a superexposição da imagem de Neymar pode ser justificada pela importância e necessidade das relações estabelecidas entre o esporte e a indústria midiática. Segundo Foucault (1996), não é uma história qualquer que será reproduzida. Diante dessa assertiva, o ato de repercutir histórias revela que certos discursos se estabelecem como mecanismos de legitimação de seu próprio exercício enunciativo, instituindo sua autoridade e inscrição social. Observando essa lógica, percebe-se que o discurso jornalístico é uma instituição discursiva que cria textos e os inscreve no espaço coletivo da recepção para manifestar sua influência e seu impacto no imaginário dos receptores, inclusive sobre esporte e atletas.

No entanto, identifica-se também nas enunciações do G2, intertextualidade referente ao papel do ídolo Neymar como modelo a ser seguido pela sociedade e capaz de difundir a identidade brasileira mundo afora. Os estudantes concordam com a crítica feita por Pelé e empregam um discurso que exalta o princípio formativo e educador do esporte como elemento social que se encarrega de repassar valores éticos e morais.

Eu acho que por ele ser muito jovem e essa ascensão na carreira ter sido muito rápida, o Neymar começou a ficar iludido com a fama e acabou esquecendo os valores que ele tem que passar como ídolo do futebol. (Aluna 5, G2)

Os sujeitos do G1 julgaram que o discurso da matéria defende o jogador Neymar dos "ataques" de Pelé e ecoa uma oposição clara e constante entre os dois, mostrando-os como "mocinho" (Neymar) e "vilão" (Pelé). Aliado a esse discurso, a matéria se mostrou claramente persuasiva ao utilizar a "linguagem da televisão", com informações rápidas, descontextualizadas, intensificando sua campanha pró-Neymar. A informação, então, passou para segundo plano e o espetáculo se apoderou da tela.

Essa distinção clara entre o bem e o mal, entre Neymar e Pelé, pode ganhar vida na cabeça de algumas pessoas mais vulneráveis. Aqueles mais influenciáveis pela televisão podem ficar passivos diante dessas imagens e desse texto. As realizações, as ideias, os pensamentos, as falas de Neymar passariam a ser representações dessas pessoas. (Aluna $7, \mathrm{G} 1$ )

O conflito usualmente presente nos roteiros de filmes e novelas, também é pauta do telejornalismo. Dentro do contexto já pré-estabelecido, os papéis que serão incorporados na narrativa começam a ser delineados. O vilão será aquele que praticou alguma ação contrária à lei, à moral ou à consciência e, por isso, deverá ser punido. O lesionado (ou no caso, criticado) será protegido e deve receber uma recompensa. As narrativas televisivas cumprem essa orientação: oferecer ao telespectador a ilusão de que sempre existirão mocinho e vítima na ficção e realidade (ANGRIMANI SOBRINHO, 1995).

Essa discussão é pertinente pelo fato de indicar a interferência do discurso da mídia no sistema de representações. Nas representações proporcionadas pela televisão, a narrativa é 
realizada através de mediação, uma vez que surge para os telespectadores através de repórteres, porta-vozes, testemunhas e outros sujeitos falantes julgados capazes de construir versões do ocorrido. Os efeitos sonoros e de imagem e a narrativa da peça 1 pode interferir na formação de opiniões e comportamentos. A representação do embate entre Neymar e Pelé segue algumas regras da própria narrativa como, por exemplo, a necessidade de que o fato narrado tenha começo e fim, entre os quais se configure gradualmente um efeito de sentido, obtido através da utilização de elementos argumentativos, destinados a captar a atenção e a aprovação do sujeito.

Os integrantes do G1 afirmaram que tendo a matéria designado às personagens centrais as representações de vilão e mocinho da estória, o princípio da imparcialidade - um dos pilares do jornalismo - não foi respeitado pela reportagem. A cultura da mídia expressa por Kellner (2001) tem em seu centro uma arena de disputa de poder, na qual os sujeitos são espectadores de um bombardeio político-ideológico e "vivenciam essas lutas por meio de imagens, discursos, mitos e espetáculos veiculados pela mídia" (KELLNER, 2001, p. 11).

\section{CONSIDERAÇÕES FINAIS}

Para que um espetáculo seja ofertado é preciso encontrar atores que façam parte desse processo. Por isso, a mídia nomeia algumas pessoas para serem consumidos pela audiência, por meio de um bombardeio de imagens. Agindo como elemento preponderante do esporteespetáculo, a mídia converte seus principais atores em ídolos, produz peças de comunicação e cria um circuito de produção e consumo. A imagem dos atletas-ídolos é um investimento vantajoso, pois, devido ao talento profissional e ao carisma agradam aos receptores - e sustentam a venda de produtos, movimentando o mercado - e, pela carga simbólica, facilitam a identificação do receptor com a mensagem que se quer transmitir. Não basta o atleta exercer sua função como profissional do esporte, é preciso entender que os ídolos são modelos para o público e seus feitos têm forte ligação no processo de formação da sua marca.

A apropriação crítica do discurso midiático é parte de um processo que incita os indivíduos a observarem o processo de seleção de determinada informação, e por que temas são omitidos e outros tratados com mais ênfase nas notícias. O discurso dos sujeitos da pesquisa explicita o protagonismo de matérias como a produzida pelo EE como principais responsáveis pela representação de Neymar na sociedade. Para os participantes, Neymar não é um simples jogador de futebol, mas um astro que se tornou garoto propaganda de diversas marcas mundiais e cuja carreira tem sido construída não apenas nos gramados, mas também em torno de uma imagem eficaz e cuidadosamente gerida por uma agência de assessoria e por veículos de comunicação como, por exemplo, o programa Esporte Espetacular. Dessa forma, o EE explora o carisma e a suposta espontaneidade de Neymar, seu estilo e visual diferenciado, e através da espetacularização da mídia oferece uma reflexão de sobre como os sujeitos devem se comportar e se apresentar.

Neymar foi percebido pelos sujeitos da pesquisa como uma produção da mídia que o trata, ao mesmo tempo, como sujeito e mercadoria, uma marca. Essa configuração de Neymar como ídolo se configuraria como um modo de controle social pelo grupo hegemônico na sociedade. $\mathrm{O}$ ídolo Neymar é ícone da redenção do oprimido, pois daria aos excluídos a possibilidade de visualizar perspectivas de mudança da sua condição social. 


\section{REFERÊNCIAS BIBLIOGRÁFICAS}

1. ANGRIMANI SOBRINHO, D. Espreme que sai sangue: um estudo do sensacionalismo na imprensa. São Paulo: Summus, 1995. (Coleção Novas Buscas em Comunicação, v. 47)

2. ARBEX JUNIOR, J. Showrnalismo: a notícia como espetáculo. São Paulo: Casa Amarela, 2001.

3. BARTHES, R. Mitologias. 11. ed. Rio de Janeiro: Bertrand Brasil, 2001.

4. BOURDIEU, Pierre. O poder simbólico. Rio de Janeiro: Bertrand Brasil, 1989.

5. . A distinção: crítica social do julgamento. São Paulo: Edusp, 2007.

6. CAMPBELL, Colin. Eu compro, logo sei que existo: as bases metafísicas do consumo moderno. In: BARBOSA, L.; CAMPBELL, C. (Orgs.). Cultura, consumo e identidade. Rio de Janeiro: FGV, 2006. p. 47-64.

7. ChARAUDEAU, P. Discurso das mídias. 2. ed. São Paulo: Contexto, 2010.

8. DEBORD, G. A sociedade do espetáculo. São Paulo: Contraponto, 1997.

9. FOUCAULT, Michel. A ordem do discurso. 3. ed. São Paulo: Edições Loyola, 1996.

10. Microfísica do poder. 25. ed. Rio de Janeiro: Graal, 2008.

11. HALL, Stuart. A Identidade Cultural na Pós-Modernidade. 10. ed. Rio de Janeiro: DP\&A, 2005.

12. HELAL, R. A construção de narrativas de idolatria no futebol brasileiro. Alceu, v. 4, n. 7, p. 1936, jul./dez. 2003.

13. KELLNER, D. A Cultura da Mídia - estudos culturais: identidade e política entre o moderno e o pós-moderno. Bauru: EDUSC, 2001.

14. ___ A cultura da mídia e o triunfo do espetáculo. Revista Líbero, v. 6, n. 11, p. 4-15. 2004.

15. MAINGUENEAU, Dominique. Novas tendências em análise do discurso. 3. ed. Campinas: Editora da UNICAMP, 1997.

16. MARCONI, M.A.; LAKATOS, E.M. Técnicas de pesquisa: planejamento e execução de pesquisas, amostragens e técnicas de pesquisa, elaboração análise e interpretação de dados. 7. ed. São Paulo: Atlas, 2009. 277 p.

17. MARTÍN-BARBERO, J. Dos meios às mediações: comunicação, cultura e hegemonia. 6. ed. Rio de Janeiro: Ed. UFRJ, 2009.

18. MINAYO, Maria Cecilia de Souza. 0 desafio do conhecimento: pesquisa qualitativa em saúde. 11. ed. São Paulo: Hucitec, 2008.

19. MUNARETTO, L.F.; CORRÊA, H.L.; CUNHA, J.A.C. Um estudo sobre as características do método Delphi e de grupo focal, como técnicas na obtenção de dados em pesquisas exploratórias. Rev. Adm. UFSM, v. 6, n. 1, p. 09-24, jan./mar. 2013.

20. TRAQUINA, N. Jornalismo: questões, teorias e "estórias". 2. ed. Lisboa: Vega, 1999.

21. VERÓN, E. Fragmentos de um tecido. São Leopoldo: Ed. Unisinos, 2004.

22. VYGOTSKY, L.S. Psicologia pedagógica. 2. ed. São Paulo: Martins Fontes, 2004.

23. WOLF, Mauro. Teorias da comunicação. Lisboa: Editorial Presença, 1995. 